\title{
Lidia Kłos
}

Uniwersytet Szczeciński

e-mails: lidia.klos@wneiz.pl; lidia.klos@usz.edu.pl

ORCID: 0000-0001-7573-2626

\section{WYMIAR SPÓJNOŚCI UNII EUROPEJSKIEJ}

W PRZECIWDZIALANIU

„PLANOWANEMU POSTARZANIU PRODUKTU”

\section{THE DIMENSION OF COHERENCE OF THE EUROPEAN UNION AGAINST "PLANNED AGING OF PRODUCTS"}

DOI: $10.15611 /$ pn.2018.536.07

\begin{abstract}
Streszczenie: Ulegający skróceniu okres żywotności różnego rodzaju sprzętu oraz coraz częstsza awaryjność jest ściśle związana ze zjawiskiem ,planowanego postarzania produktu”. Celem artykułu jest przedstawienie współczesnego wymiaru ,zaplanowanej nieprzydatności produktu”, które zrodziło się już w latach 20. XX wieku, oraz wskazanie, jakie działania Unia Europejska podejmuje w kierunku przeciwdziałania temu zjawisku. W tym celu w artykule wykorzystano badania, które w 2016 roku opublikowała niemiecka Federalna Agencja Środowiska (UBA) ${ }^{1}$, potwierdzające praktykę postarzania produktów, oraz przedstawiono analizę dokumentów, jakie Unia Europejska opublikowała w celu ograniczenia tego procederu. Artykuł ma charakter badawczo-opisowy.
\end{abstract}

Słowa kluczowe: zaplanowana nieprzydatność, konsumpcja, świadomy klient, środowisko.

Summary: Reduced lifespan of different types of everyday equipment and more and more frequent failures is strictly related to the phenomenon of "planned obsolescence". The aim of this article is to present the "planned obsolescence" and to indicate what actions the European Union is taking to counteract this phenomenon. For this purpose, the article uses research which in 2016 was published by the German Federal Environment Agency (UBA), confirming the practice of aging of products and an analysis of documents that the European Union published in order to limit this practice. The article has a research-and-descriptive character.

Keywords: planned obsolescence, consumption, conscious customer, environment.

${ }^{1}$ UBA - Umwelt Bundes AMT, Niemiecka Federalna Agencja Środowiska, założona w 1974 r. jako centralny urząd administracji rządowej Niemiec w sprawach dotyczących środowiska, http://www.proakademia.eu/baza-partnerow-3/19.html (18.01.2018). 


\section{Wstęp}

Współcześnie coraz częściej daje się zauważyć, że znacznie skrócił się okres żywotności urządzeń. Jeszcze 15 lat temu pralki czy lodówki pracowały po kilkanaście lat. Dziś o połowę krócej. Efekt jest taki, że przeciętny Europejczyk co 5-7 lat wymienia sprzęt RTV i AGD, komputer co 3 lata, a komórkę - co półtora roku (Raport Niemieckiej Federalnej Agencji Środowiska 2016). To masa zmarnowanych surowców i energii oraz tony elektrośmieci, które trafiają do środowiska [Dokąd trafiają elektrośmieci... 2018].

Istnieje wiele dowodów na to, że celowe jest projektowanie produktów w taki sposób, aby po krótkim czasie użytkowania nadawały się do wymiany na nowszy model. Telefony, pralki, lodówki, telewizory... to sprzęt, bez którego dziś nie da się funkcjonować. Kilkanaście lat temu, gdy kupowało się telewizor, można było mieć pewność, że posłuży przynajmniej dekadę. Podobnie było z innymi urządzeniami, dziś zwykle „zużywają się” zaraz po upływie terminu gwarancji i wymuszają na nas kolejny zakup częstokroć droższego produktu. Opisane powyżej sytuacje definiuje się jako celowe (planowane) postarzanie produktu - świadome skracanie cyklu produktu (planned obsolescence) [Ryś 2015, s. 121]. Planowane postarzanie produktu zrodziło się już w latach 20. XX wieku. Po raz pierwszy w literaturze zaplanowana nieprzydatność pojawia się już w 1932 roku jako jeden ze środków na walkę z krachem ekonomicznym lat $30 .^{2}$

Artykuł ma charakter opisowo-badawczy i przybliża współczesny wymiar ,zjawiska planowanego postarzania produktu" oraz analizę podejmowanych działań w badanym zakresie na forum Unii Europejskiej.

\section{A zaczęło się tak niewinnie - „spisek żarówkowy", pierwsza historia zaplanowanej nieprzydatności}

Zaczęło się od słynnego „spisku żarówkowego"3. Kiedy Thomas Edison opatentował żarówkę (którą produkowano już od 1881 r.), jej żywotność wyniosła ok. 1500 roboczogodzin. Do roku 1924 producenci prześcigali się w przedłużaniu trwałości żarówek, w efekcie czego poprawili jej wydajność aż do 2500 godzin, choć byli i tacy, którzy chwalili się, że ich produkt świeci około 3000 godzin. W tym samym roku doszli jednak do wniosku, że produkcja tak trwałych żarówek jest nieopłacalna, ponieważ nasycenie rynku spowoduje spadek sprzedaży. Dla producentów korzystniej jest, jeżeli konsumenci dokonują zakupów cyklicznie w możliwie krótkich od-

2 Zaplanowana nieprzydatność produktów pojawiła się wraz z rozwojem masowej produkcji. W momencie kiedy produkty stawały się tańsze, ludzie kupowali nie tylko rzeczy potrzebne do życia, ale również te, które zaspokajały potrzeby wyższe [An economic... 1986].

${ }^{3}$ Film dokumentalny: „Spisek żarówkowy”, reż. Cosima Dannoritzer, Spisek żarówkowy, produkcja Francja - Hiszpania, 2010. 
stępach czasu. Tak powstał pierwszy na świecie kartel - Phoebus ${ }^{4}$, którego celem było ograniczenie trwałości żarówek. Najwięksi producenci (Osram, Philips i General) zawarli wówczas porozumienie, które zobowiązało sygnatariuszy do zmniejszenia żywotności żarówek do 1000 godzin. Kartel ten sprawił, że po raz pierwszy w historii przedmiot codziennego użytku został zmodyfikowany tak, by szybciej się psuć. Kto wyłamał się z porozumienia, płacił wysokie kary. Do początku lat 40. XX wieku wszyscy osiągnęli zamierzony pułap i na rynku ciężko było kupić żarówkę, która świeciłaby dłużej niż ustalony limit 1000 godzin. Kartel, mimo że był nieformalny, skupił w sobie głównych producentów żarówek w USA, Europie i Japonii; mimo wykrycia spisku sytuacja nie zmieniła się do dzisiaj.

Kolejnym przykładem podobnych praktyk był amerykański koncern DuPont, który od 1935 roku rozpoczął pracę nad nylonem - materiałem, który w krótkim czasie zrewolucjonizował branżę tekstylną. Nylonowe pończochy wyparły dotychczasowe, $\mathrm{z}$ bawełny i jedwabiu. W tym momencie pojawił się problem - zadowolone klientki rzadziej kupowały pończochy, a więc to co stało się dobrodziejstwem dla konsumenta przyczyniło się do strat producenta. Zarząd firmy nakazał rozwiązanie „tej kwestii”. W tym przypadku sprawa okazała się prosta: emitowane przez słońce promieniowanie ultrafioletowe powoduje, że włókna nylonowe stają się kruche i łamliwe. Zapobiegały temu specjalne dodatki zawarte w pierwszych pończochach, $\mathrm{w}$ tej sytuacji z nich zrezygnowano. W ten sposób firmy zapewniły sobie stały dochód, a kobiety do dziś muszą walczyć z oczkami [Huma 2013].

\section{Współczesny wymiar, ,zaplanowanego postarzania produktu”}

Planowe postarzanie produktu ewaluowało przez kolejne dekady. Obecnie cała procedura polega na wprowadzaniu na rynek coraz nowszych, bardziej zaawansowanych produktów, które wypierają z rynku produkty starsze, ale niekoniecznie gorsze. W metodzie zaplanowanego postarzania produktu chodzi o to, by klient sam potrzebował nowego urządzenia, np. telefonu, możliwie szybko i z pełnym przekonaniem. W tym celu wykorzystuje się działania marketingowe, które mają nas przekonać o konieczności zakupu nowego znacznie lepszego i bardziej na czasie egzemplarza [Kozłowski 2018]. Jeśli chcesz być na czasie, nie wypada ci mieć starego modelu urządzenia. Potrzebujesz nowego, choć stare ci jeszcze służy. Musisz mieć nowy telefon, z większym wyświetlaczem, większą liczbą funkcji, choć najczęściej nigdy z nich nie korzystasz. Innym sposobem na „zmotywowanie” klienta do zakupu nowego modelu jest pogorszenie działania obecnie używanych przez konsumentów urządzeń. W niektórych na przykład zmienia się gniazda, nowe mają już inny kształt, inne parametry. W efekcie nie wystarczy zmienić wzmacniacz, musisz do niego dokupić nowy egzemplarz - lepszy, dający więcej możliwości. Wreszcie producenci idą dalej, pro-

${ }^{4}$ Oficjalna nazwa kartelu - Phoebus S.A. Compagnie Industrielle pour le Developpment de l'Eclairage [Huma 2018]. 
gramują urządzenie tak, by zepsuł się w nich element, którego cena spowoduje nieopłacalność zakupu. Takimi elementami są np. programatory pralek, zmywarek. Podobnych sztuczek producenci mają więcej - w niektórych zmywarkach do naczyń lub kuchenkach elektrycznych instaluje się słabej jakości podzespoły, które pod wpływem wysokiej temperatury zużywają się dwa razy szybciej. Również niektóre urządzenia wyposażone są w liczniki, które po wykonaniu odpowiedniej liczby cykli po prostu je wyłącza, wskazując klientowi awarię. Kolejnym sposobem planowanego postarzania produktu jest stosowanie niższej jakości materiałów oraz budowanie urządzeń, tak żeby wymiana zużywających się elementów była trudna lub wręcz niemożliwa do przeprowadzenia przez serwis, np. baterie telefonów [http://www.spidersweb. pl/2015/04/planowane-postarzanie-produktu.html].

W przypadku sprzętu elektronicznego odbywa się to przez odpowiednio zaprogramowane ,antyfunkcje” poszczególnych urządzeń. Chodzi o to, że pewne elementy gotowych produktów są zaprogramowane tak, aby przestały działać po określonym czasie lub wykonaniu określonej liczby czynności (najczęściej zaraz po upływie okresu gwarancji). Problem w tym, że wiele takich zabiegów jest praktycznie nie do udowodnienia, a producent zawsze może się thumaczyć stwierdzeniem, że sprzęt nie był używany zgodnie z instrukcją. Przykładem mogą być drukarki, w których wbudowane chipy nie pozwalają zużyć całego tuszu do końca i blokują się po określonej liczbie wydruków. Tymczasem po zainstalowaniu odpowiedniego oprogramowania drukarka może działać dalej bez zastrzeżeń. Czyli została celowo zaprogramowana tak, by nie eksploatować swoich zasobów do końca [Duź 2017].

Niechlubnym przykładem tego procederu jest proces, jaki w $2013 \mathrm{r}$. wytoczono firmie Apple. Baterie w produkowanych przez firmę iPodzie Nano $1 \mathrm{G}$ celowo były obliczone na krótką żywotność (poniżej okresu gwarancji, która wynosiła 1 rok). Dodatkowym skandalem było to, że nie dało się ich wymienić i klient był zmuszony do zakupu nowego odtwarzacza. Proces zakończył się ugodą, a firma Apple zobowiązała się wprowadzić procedurę wymiany baterii i przedłużyła gwarancję do 2 lat.

\section{Przegląd dostępnych wyników badań na temat planowanego postarzania produktów}

W 2013 roku niemiecka partia Zielonych zleciła badania, które obejmowały producentów. Raport przygotowany przez specjalną grupę rzeczoznawców i opublikowany w 2016 r. nie pozostawiał wątpliwości5. Producenci sprzętu AGD i RTV celowo projektują go tak, by zepsuł się w odpowiednim momencie, najczęściej po upływie okresu gwarancji.

Według raportu w ostatnim czasie najmocniej skrócił się czas użytkowania przez klientów: telewizorów, lodówek oraz zmywarek (rys. 1). Naukowcy pracujący na

${ }^{5}$ Ostateczna wersja raportu ukazała się w 2016 r., chociaż wstępne wyniki były już publikowane w $2015 \mathrm{r}$. 


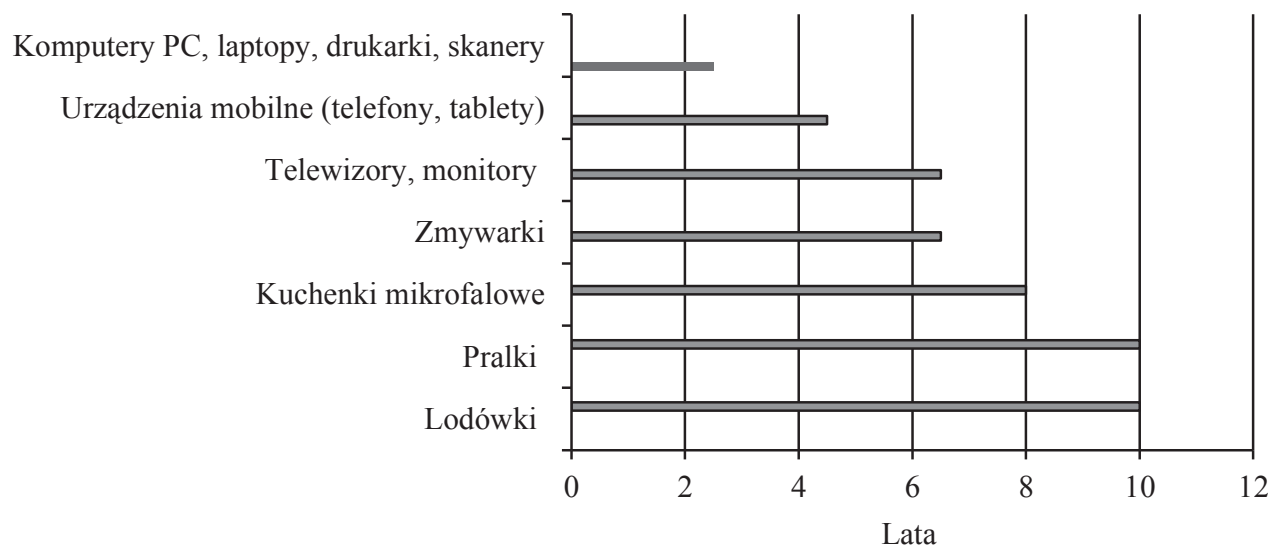

Rys. 1. Średni czas eksploatacji urządzenia

Źródło: opracowanie własne na podstawie Raportu Federalnej Agencji Ochrony Środowiska.

zlecenie Federalnej Agencji Ochrony Środowiska dowiedli, że średni cykl życia telewizora kineskopowego wynosił 10-11 lat. Obecne na rynku płaskie telewizory przeważnie wymieniamy po 5-6 latach. W ciągu ostatnich kilkunastu lat o 1,5 roku (z 15,5 do 14 lat) skrócił się czas bezawaryjnej pracy lodówek.

Zmianie ulegają również powody, dla których konsumenci wymieniają sprzęt na nowy. Jeszcze w 2004 roku w blisko 70\% impulsem do zakupu nowego urządzenia była chęć posiadania lepszego sprzętu. Jednak już w 2013 roku z tego samego powodu nowe urządzenia gotowych było kupić tylko $25 \%$ użytkowników. Na przełomie tych lat doszło też do drastycznego wzrostu - z 5\% do 25\%, liczby przypadków, w których klient decydował się na zakup nowego urządzenia ze względu na wystąpienie nienaprawialnej wady.

Dodatkowo wyliczono, że zaprogramowane starzenie kosztuje niemieckich konsumentów około 5-6 mld euro. Ile kosztuje to przeciętnego Kowalskiego w Polsce, na razie nikt nie próbował oszacować - w końcu od dobrych kilkunastu lat nurzamy się w konsumpcji, odreagowując braki socjalistycznego handlu. Ale również nasze organizacje konsumenckie notują ostatnio więcej skarg na produkty, które psują się coraz częściej, i to tuż po wygaśnięciu gwarancji.

Potwierdzają to badania przeprowadzone przez A. Rysia ${ }^{6}$, z których wynika, że również polskie społeczeństwo nie jest wolne od tego zjawiska. Ponad $86 \%$ respondentów odpowiedziało twierdząco, że znany jest im proceder „postarzania produktu”. Najczęściej wśród produktów dotkniętych ,problemem postarzania” badani wy-

${ }^{6}$ Dr inż. Adam Ryś z Akademii Górniczo-Hutniczej w Krakowie w sierpniu 2015 r., posługując się ankietą internetową, przeprowadził badanie recepcji na polskim rynku zjawiska planowanego postarzania produktu [Ryś 2016, s. 83-98]. 
mienili: drukarki, żarówki, telefony komórkowe, sprzęt AGD i RTV oraz komputery, laptopy i części motoryzacyjne. Konkretne marki to: HP, Epson, Toyota czy Apple. Ostatecznie respondenci potwierdzili, że najwięcej przypadków planowanego postarzania produktów dotyczy branży: RTV i AGD - 80\% ankietowanych. Na drugim miejscu wskazano motoryzację - 69\%, komputery i telefony $-63 \%$ ankietowanych.

Wśród sposobów, według których producenci dokonują planowanego postarzania produktu, najczęściej wskazano, takie jak: budowa uniemożliwiająca naprawę lub zwiększająca jej koszt (ponad 88\% badanych), awaryjne podzespoły, które są zaprojektowane tak, aby po zaliczeniu pewnej liczby cykli zablokować możliwość dalszego użytkowania. Kolejne wskazania to: brak wsparcia dla produktów już nieprodukowanych lub po okresie gwarancji, materiały złej jakości, niestandardowe części i pojawienie się nowego, atrakcyjnego wizualnie modelu z lepszymi funkcjami lub w lepszej cenie [Ryś 2016, s. 91-91].

\section{Działania podejmowane na forum Unii Europejskiej $\mathrm{w}$ walce $\mathrm{z}$,planowanym postarzaniem"}

Unia Europejska podjęła walkę z praktykowaniem przez wytwórców planowania awaryjności produktów. Rozwiązaniem ma być gospodarka o obiegu zamkniętym (tzw. circular economy). Ma ona polegać na minimalizacji wpływu na środowisko produkowanych dóbr. Podczas produkcji mają być dobierane takie komponenty, aby po ich wyeksploatowaniu można było ponownie je wykorzystać [UE chce walczyć...]. Włączanie do ponownego obiegu zużytych surowców ma przyczynić się, według ekspertów, do wzrostu europejskiego PKB nawet o 11\% do roku 2013 oraz o 27\% do 2050 roku [Circular economy 2016]. Praktykowanie gospodarki o obiegu zamkniętym ma także wpłynąć na wzrost zatrudnienia, nie tylko w sektorze recyklingu, ale także w dziedzinie logistyki, innowacyjności. Niestosowanie toksycznych chemikaliów oraz wielokrotne wykorzystywanie surowców, według Fundacji Ellen Mac Arthur, przyczyni się do zmniejszenia emisji dwutlenku węgla średnio o połowę w stosunku do obecnego stanu. Zostanie również wyeliminowany problem składowania odpadów, ponieważ większość z nich zostanie powtórnie wykorzystana.

Istotną rolę $\mathrm{w}$ walce $\mathrm{z}$ planowanym postarzaniem ma odgrywać opracowana przez Unię Europejską Dyrektywa Ekoprojekt (Ecodesign). Ma ona na celu nakłonienie wytwórców, aby wprowadzane przez nich na rynek produkty były trwalsze, służyły dłużej oraz były prostsze w naprawie. Na etykietach mają znajdować się informacje na temat szacowanego czasu użytkowania danego urządzenia. Planowane jest także wprowadzenie obowiązku utylizacji przez producentów sprzętów, które się popsuły. Dzięki temu produkowanie trwalszych towarów będzie bardziej opłacalne dla wytwórców, ponieważ będą oni dążyli do minimalizacji ponoszonych kosztów związanych z przetwarzaniem zepsutych urządzeń. Dla przykładu we Francji pojawił się pomysł dopuszczenia do sprzedaży tylko urządzeń mobilnych, które 
będą miały wymienne akumulatory. Na producentach chce się też wymusić 5-letnią gwarancję oraz obowiązek zapewnienia dostępności części zamiennych przez 10 lat od momentu wprowadzenia danego urządzenia na rynek [Nowak 2015].

Wielu ludzi chce również walczyć ze zjawiskiem postarzania produktów. Tak właśnie zrodziła się postawa świadomego konsumenta. Osoby przyjmujące to stanowisko zwracają uwagę na miejsce i warunki powstawania produktów, ich skład, jakość oraz wpływ na środowisko [Salus 2016].

\section{Zakończenie}

Planowane postarzanie produktu zaczęło się od regulacji kartelu żarówkowego, ale obecnie jest już widoczne praktycznie we wszystkich gałęziach produkcji i handlu. Współcześnie nastąpiło zintensyfikowanie zjawiska „postarzania produktu”, w efekcie czego pojawiły się nowe sposoby na ograniczenie trwałości wyrobów, m.in. przez zaprzestanie produkcji części zamiennych, budowę uniemożliwiającą naprawę, używanie materiałów nietrwałych, awaryjnych podzespołów zużywających się po upływie określonego czasu oraz montowanie chipów unieruchamiających urządzenie. Globalny zakres zjawiska wymaga zintensyfikowania działań w celu efektywnego przeciwdziałania temu procederowi, które to podejmowane są na forum Unii Europejskiej.

\section{Literatura}

An economic theory of planned obsolescence, 1986, quarterly Journal of Economics, https://facultygsb. stanford.edu/bulow/articles/an\%20economic\%20theory\%20of\%20planned\%20obsolescence.pdf.

Circular economy nakręci europejska gospodarkę?, 2016, http://portalkomunalny.pl/circular-economy-polska-gospodarka-332263 (17.01.2018).

Dokąd trafiaja elektrośmieci z Europy, https://www.oostdam.pl/dokad-trafiaja-elektrosmieci-z-europy/ (17.01.2018).

Duź S., 2014, Materializm i konsumpcjonizm niszcza cywilizację Zachodu, https://wolnemedia.net/ materializm-i-konsumpcjonizm-niszcza-cywilizacje-zachodu/ (17.01.2018).

Film dokumentalny: „Spisek żarówkowy”, reż. Cosima Dannoritzer, produkcja Francja - Hiszpania, 2010.

Hamrol A., Najlepszy Z., 2013, Za i przeciw planowanemu ograniczaniu trwatości wyrobów, Inżynieria Maszyn, r. 18, z. 1, s. 118-126.

Huma M., 2013, Planowane postarzanie, http://www.ekonsument.pl/a66697_planowane_postarzanie. $\mathrm{html}$.

Jakie sa podstawowe przepisy prawne dotyczace dyrektywy ErP?, http://www.buderus.pl/buderus-on-line/dyrektywa-erp/przepisy-prawne.html (18.01.2018).

Kozłowski T., Szczęście: niespetniony dogmat doby konsumpcjonizmu?, Psychologiczne uwarunkowania poczucia dobrostanu a spoleczno-kulturowa praktyka, http://www.anthropos.us.edu.pl/anthropos11/texty/kozlowski.html (15.01.2018).

Nowak M., 2012, Planowane postarzanie produktu przez producentów to nie mit, http://www.spidersweb. pl/ 2012/07/planowane-postarzanie-produktu-przez-producentow—nie-mit.html (17.01.2018). 
Nowak M., 2015, Koniec z mitem. Za planowanym postarzaniem produktów stoją teraz fakty i konkretne liczby, http://www.spidersweb.pl/2015/04/planowane-postarzanie-produktu.html (17.01.2018).

Prakash S., Dehoust G., Gsell M. i in., 2015, Raport UBA, Einfluss der Nutzungsdauer von Produkten auf ihre Umweltwirkung: Schaffung einer Informationsgrundlage und Entwicklung von Strategien gegen ,, Obsoleszenz”, Umwelt Bundesamt, Dessau-Roslau 2016. https://www.umweltbundesamt. de/sites/default/files/medien/378/publikationen/texte_11_2016_einfluss_der_nutzungsdauer_ von_produkten_obsoleszenz.pdf (15.01.2018).

Raport Niemieckiej Federalnej Agencji Środowiska z 2016r. https:/www.spidersweb.pl/2015/04/planowane-postarzanie-produktu.html (18.01.2018).

Ryś A., 2015, Planowane postarzanie produktu - analiza zjawiska, Zeszyty Naukowe Wyższej Szkoły Humanitas. Zarządzanie, Sosnowiec.

Ryś A., 2016, Planowane postarzanie produktów - wyniki badań pierwotnych, ZNWSH, Zarządzanie, (1), s. 83-89.

Salus K., 2016, Konsument świadomy swojej sity, http://www.ekonsument.p1/a66987_konsument_ swiadomy_swojej_sily.html (18.01.2018).

UE chce walczyć ze zbyt szybko psującym się sprzętem elektronicznym, 2016, https://www.pb.pl/uechce-walczyc-ze-zbyt-szybko-psujacym-sie-sprzetem-eletronicznym-824159 (17.01.2018).

http://www.proakademia.eu/baza-partnerow-3/19.html (18.01.2018).

http://www.spidersweb.pl/2015/04/planowane-postarzanie-produktu.html (15.01.2018). 